\section{VIRUS ISOLATIONS FROM COMMON COLDS OCCURRING IN A RESIDENTIAL SCHOOL}

BY

\section{E. J. C. KENDALL, M.B., M.R.C.P.}

M. L. BYNOE, M.B., D.T.M.\&H., D.Obst.R.C.O.G.

\section{AND}

\section{A. J. TYRRELL, M.D., M.R.C.P}

From a General Practice, Epsom, and the Medical Research Council's Common Cold Research Unit, Salisbury, Wilts

In recent years viruses of a hitherto uncultivable type have been isolated from nasal washings collected from adults suffering from the common cold (Tyrrell and Parsons, 1960 ; Hobson and Schild, 1960 ; Tyrrell and Bynoe, 1961 ; Hamre and Procknow, 1961). The viruses can be cultivated in rolled tissue cultures of humanembryo-kidney cells maintained at $33^{\circ} \mathrm{C}$. They produce a focal cytopathic effect. It has been suggested that they be called rhinoviruses (Andrewes et al., 1961). There is evidence that all the strains adequately studied produce colds when administered to volunteers as nasal drops and that the type of illness produced may vary a little, depending on the strain used. The viruses belong to two main biological types-namely, those which grow in human embryo-kidney and in monkey-kidney cells (M) and those which grow only in human-embryokidney cells $(\mathrm{H})$; it has been shown also that some washings contain agents which have not yet been shown to grow in either of these cell types (Tyrrell and Bynoe, 1961).

We were anxious to make a longitudinal study to determine if viruses could be found consistently in young persons with common-cold symptoms, and, if so, to obtain a full record of illness. We also hoped to obtain some data of epidemiological importance. Such a pilot study is described in this paper. It was made as part of a general surveillance of respiratory illnesses which significantly affect school attendance.

\section{Materials and Methods}

The common colds studied occurred among boarders at a boys' school which was under the medical care of one of us (E. J.C.K.). The age constitution of this group is given in Table $\mathrm{I}$. The boys were observed

TABle I.-Age Constitution of Group, Incidence of Colds, and Numbers of Illnesses Investigated 1960-1

\begin{tabular}{|c|c|c|c|c|c|}
\hline Year of Birth: & $1947-8$ & 1946 & 1945 & 1944 & $1942-3$ \\
\hline $\begin{array}{l}\text { No. of boys in group on } 1161 \ldots \\
\text { Incidence of common colds }\end{array}$ & $\begin{array}{l}84 \\
67 \\
80 \%\end{array}$ & $\begin{array}{l}68 \\
48 \\
70 \%\end{array}$ & $\begin{array}{l}60 \\
34 \\
57 \%\end{array}$ & $\begin{array}{l}79 \\
46 \\
58 \%\end{array}$ & $\begin{array}{l}77 \\
30 \\
39 \%\end{array}$ \\
\hline $\begin{array}{l}\text { No. of virus-positive illnesses/No. } \\
\text { of illnesses investigated }\end{array}$ & $9 / 23$ & $2 / 14$ & 29 & 12 & 411 \\
\hline
\end{tabular}

during those parts of the school terms included between June 14, 1960, and June 13, 1961. Eighty of the older boys left the school during the study and were replaced by an equal number of younger boys. The majority of these changes took place between July and September, 1960. The boarders were organized in eight groups (Houses), but lived in only five separate buildings. There were many opportunities, therefore, for cross-infection to occur during lessons, when they were segregated by age, and at other times when they were grouped in Houses. The 150 boys who attended all classes in the school and lived at home were not included in this study.

All medical treatment was provided at the school sanatorium, where boys were seen daily. Symptoms and signs were recorded methodically on a special form. Mouth temperatures were recorded by the nursing staff, daily for out-patients and twice daily for boys admitted to the sanatorium. In-patients were seen daily, while out-patients were seen three to five times during their illnesses. Boys were kept under observation until the acute stage of the illness was over-that is, until a week or 10 days from the onset. Those boys with colds who were included in this study were provided with paper handkerchiefs and a record was kept of the number used daily.

Boys were regarded as suffering from common colds if they had an acute infection of the upper respiratory tract with nasal blockage and discharge, and if the nasal symptoms and signs were the most prominent features of their illness. We attempted to take a regular sample of the illnesses occurring among in-patients and outpatients, and, when possible, two to four illnesses were studied during each week of the survey.

\section{Specimens Collected}

Throat swabs for bacteriological examination were taken during the first few days of disease from many cases of all types of respiratory illness. In addition, swabs were taken from boys not suffering from respiratory illness. Nasal washes for virological study were taken from boys with colds within five days of onset. About $3 \mathrm{ml}$. of $10 \%$ broth saline containing antibiotics was run into each nostril, the patient's neck being fully extended; the fluid, with as much mucus as possible was then expelled into a Petri dish held by the patient. The washings were transferred to a screw-capped bottle, frozen immediately in carbon dioxide snow, and transported in this condition to the laboratory. Washings were inoculated into tissue cultures within two to three weeks of collection. We were unable to collect washings from boys without colds.

Acute- and convalescent-phase sera were obtained from some patients, and only convalescent-phase sera from others. In addition we had sera obtained from a group of boys undergoing surveillance for poliovirus antibodies in May, 1960, and May, 1961.

Washings were inoculated to human-embryo-kidney cultures as described elsewhere. Viruses of $\mathbf{M}$ type were serotyped; H-type viruses could not be studied completely owing to shortage of tissue cultures. Acute and convalescent sera were tested by routine complement-fixation tests, and the sera collected for previous studies were titrated for neutralizing antibodies against $M$ viruses isolated in the school.

\section{Results}

Our observations on respiratory disease in general are summarized in Table II, and the data on common colds are presented in more detail in the Chart. The percentage of young boys with colds was twice that of the older boys, but this may be due to differences in reporting colds between the age-groups. Common colds were seen throughout the year, but sudden rises 
TABLE II-Occurrence of Respiratory Illnesses by Clinical Categories During Six-week Periods from June, 1960, to June, 1961, and Results of Virus-isolation Studies in Cases of Common Colds

\begin{tabular}{|c|c|c|c|c|c|c|c|}
\hline \multirow[b]{2}{*}{$\begin{array}{c}\text { Period of } \\
\text { Observa- } \\
\text { tion }\end{array}$} & \multicolumn{6}{|c|}{$\begin{array}{l}\text { No. of Boys Reporting with Acute } \\
\text { Respiratory Illness }\end{array}$} & \multirow{2}{*}{$\begin{array}{l}\text { Viruses } \\
\text { Isolated } \\
\text { from } \\
\text { Colds }\end{array}$} \\
\hline & Total & $\begin{array}{c}\text { Sore } \\
\text { Throat }\end{array}$ & $\begin{array}{l}\text { Traechit is, } \\
\text { Laryngitis, } \\
\text { or } \\
\text { Bronchit is }\end{array}$ & $\begin{array}{l}\text { Pneu- } \\
\text { monia }\end{array}$ & $\left|\begin{array}{c}\text { Otitis } \\
\text { Media } \\
\text { or } \\
\text { Sinusitis }\end{array}\right|$ & $\begin{array}{l}\text { Common } \\
\text { Colds }\end{array}$ & \\
\hline $\begin{array}{l}156- \\
257 / 60 \\
25 \% 9\end{array}$ & 29 & 8 & 1 & 0 & 7 & 13 & $34^{*}$ \\
\hline 101160 & 71 & 2 & 9 & 0 & 2 & 58 & 3.12 \\
\hline $2012 / 60$ & 46 & 24 & 0 & 0 & 0 & 22 & 29 \\
\hline $\begin{array}{c}19:- \\
28 / 2 / 61 \\
1 / 3-\end{array}$ & 90 & 19 & 9 & 4 & 2 & 56 & 113 \\
\hline $\begin{array}{l}5 / 6 / 61 \\
1 / 5\end{array}$ & 56 & 10 & 5 & 1 & 2 & 38 & 211 \\
\hline $14 / 6 / 61$ & 49 & 8 & 0 & 0 & 3 & 38 & 710 \\
\hline Total & 341 & 71 & 24 & 5 & 16 & 225 & $1 8 \longdiv { 5 9 }$ \\
\hline
\end{tabular}

* Numerator = number from whom a virus was isolated. Denominator number tested.

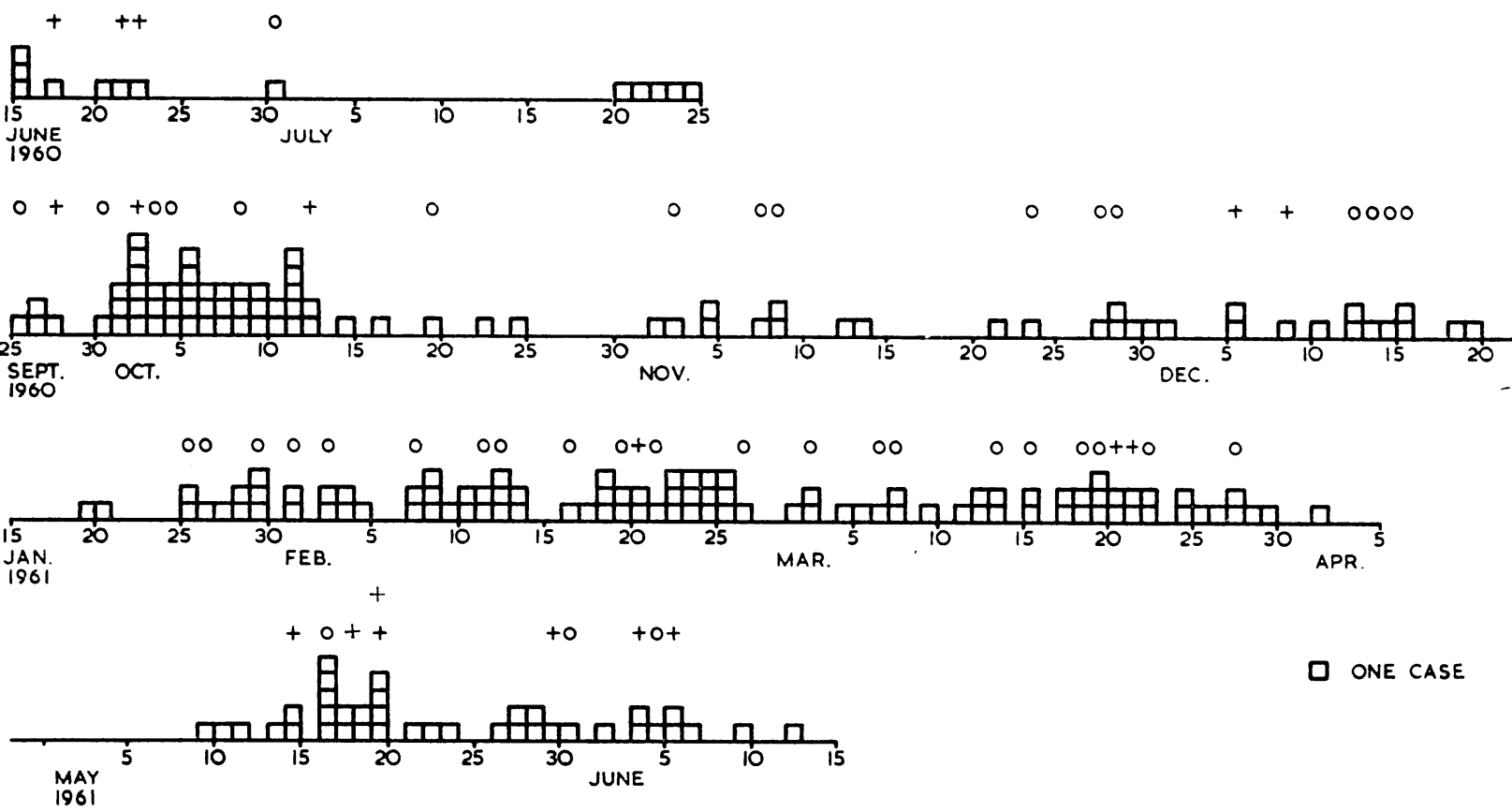

Data on common colds, Epsom College, 1960-1. $+=$ Virus isolated; $O=$ virus not isolated (one patient tested).

of incidence, such as that in October, 1960, suggested an epidemic with a new infectious agent.

It was noted that the colds studied in December, 1960, were rather severe, with fever between 100 and $103^{\circ}$ F. (37.8 and $39.4^{\circ}$ C.), constitutional symptoms, and profuse upper respiratory catarrh. During the early months of 1961 the colds were mild, but gastrointestinal symptoms (abdominal pain, nausea, vomiting, or diarrhoea) were noted in 7 out of 10 cases studied. However, as these symptoms occurred between eight days before and eight days after the onset of the cold, and as there was an outbreak of mild gastroenteritis in the school at the time, it was thought that these additional symptoms were due to coincidental infection with two agents. This was supported by experiments with volunteers (see below). The cases studied in March, 1961, were mild and included some occurring in a small outbreak among boys who were in bed for other reasons ; in April and May, 1961, the cases were similar except for transient gastro-intestinal symptoms in three.

Table II shows that the total incidence of disease fluctuated considerably and that the pattern of illness varied also. In one period only sore throat and colds were seen, while in the spring term illnesses such as otitis media, bronchitis, and pneumonia were prevalent. The cases of pneumonia were shown to be due to infection with Eaton agent.* In the third study period (November-December, 1961) cases of pharyngitis were as common as colds. The colds occurring in each period were sampled fairly uniformly, as can be seen from Table II and the Chart, but there were noticeable fluctuations in the frequency with which viruses were isolated. During the first and last period of study attempts to isolate viruses in tissue culture were usually successful, but during the spring term success was rare.

Apart from the minor deviations just mentioned the clinical picture of the 59 common colds studied was fairly uniform. At the onset, which was seldom abrupt, headache, shivering, and some soreness of the throat were common features. The nasal blockage might begin at this point, or be delayed for 24 to 48 hruurs, when it supplanted the sore throat as the main discomfort. Nasal discharge and sneezing then began. The amount of discharge, as measured by the daily handkerchief count, was a very variable feature, ranging from fewer than four handkerchiefs to 38 . Cough was sometimes a late symptom, starting up to seven days after the beginning of the cold, and persisting when other symptoms had waned.

The nasal signs were usually moderate in degree, but were more severe than those found in the throat, the latter consisting of moderate redness with slight or no oedema. The palpebral and bulbar conjunctivae were often slightly red during the first few days of the cold but there was no swelling or exudate. Abnormal cervical glandular enlargement was seldom seen. No abnormal chest signs were observed apart from a few rhonchi in one case. Non-suppurative otitis media occurred in two cases. The principal symptoms and signs are summarized in Table III. The virus-positive cases have been separated from those in which no

*This work was done by Dr. B. P. Marmion and will be reported elsewhere. 
TABLE III.-Frequency of Symptoms and Signs in Cases of Common Colds in which Virus Studies were Made

\begin{tabular}{|c|c|c|c|}
\hline & $\begin{array}{c}\text { Virus } \\
\text { Positive } \\
\text { (18 Cases) } \\
\% \\
\end{array}$ & \begin{tabular}{|} 
Virus Negative, \\
Spring, 1961 \\
(20 Cases) \\
$\%$
\end{tabular} & $\begin{array}{c}\text { Other Virus- } \\
\text { Negative Cases } \\
\text { (21 Cases) } \\
\%\end{array}$ \\
\hline 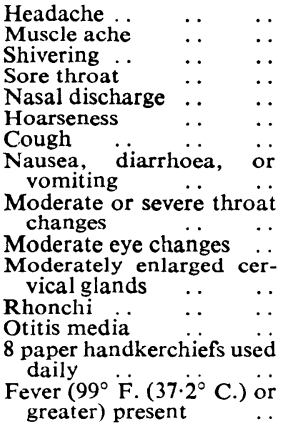 & $\begin{array}{r}61 \\
28 \\
22 \\
61 \\
100 \\
56 \\
39 \\
17 \\
39 \\
17 \\
11 \\
0 \\
0 \\
27 \\
11\end{array}$ & $\begin{array}{r}80 \\
25 \\
25 \\
65 \\
100 \\
30 \\
90 \\
55 \\
60 \\
15 \\
10 \\
5 \\
0 \\
20 \\
5\end{array}$ & $\begin{array}{r}47 \\
28 \\
28 \\
76 \\
100 \\
30 \\
62 \\
14 \\
14 \\
43 \\
5 \\
10 \\
0 \\
10 \\
9 \\
9 \\
9\end{array}$ \\
\hline $\begin{array}{l}\text { Average No. of paper } \\
\text { handkerchiefs used daily }\end{array}$ & 11 & 14 & 12 \\
\hline
\end{tabular}

isolations were made, although the latter probably include some cases caused by the same viruses. The symptoms in the virus-negative cases which occurred in the spring term of 1961 were a little different from those in the other groups in that cough, moderate or severe changes in the throat, and gastro-intestinal symptoms were more frequent. It is possible that some of these cases represent mild infections with the Eaton agent. The average severity of the disease was about the same in all groups whether measured by the number of handkerchiefs used or by the presence of fever. It can be concluded that the illnesses of those cases from which rhinoviruses were isolated were typical common colds, and similar to the illnesses produced by experimental infections with rhinoviruses in adults.

Bacteriological and Routine Serological Examinations

Throat swabs were taken from 170 of the 225 cases of common cold diagnosed during the period of observation. A moderate or heavy growth of haemolytic streptococci was obtained from $5(2.9 \%)$ of these. During the same period six similar cultures were made from a total of 214 swabs taken from boys without respiratory infection $(2.8 \%)$. All the positive cultures from the common colds were made during the summer and autumn of 1960 . For this period 5 out of 76 cultures from colds were positive $(6.5 \%)$ against 2 out of 114 controls $(1.7 \%)$. The difference is not significant $(\mathbf{P}=0.2)$. Those cases yielding streptococci had, however, more severe throat changes and their cervical lymph nodes were more of ten enlarged and tender than in the cases free from such organisms. It is possible, therefore, that these organisms were causing some part of the illness.

Paired sera from 19 cases of all types of respiratory infection were tested against the usual range of respiratory viruses. No significant (fourfold) rises were shown for influenza A, B, or C, adenovirus, Sendai virus, the psittacosis-L.G.V., or Q fever. Raised but unchanging titres, indicating past infections, were found on two occasions with influenza $\mathrm{A}$, once with influenza $\mathrm{B}$, three times with adenovirus, and twice with Sendai virus.

In summary, we detected a few cases of streptococcal infection but none of infection with the routinely studied respiratory viruses among the common colds and other respiratory infections observed in this group of boys.

\section{Virus Isolations and Neutralization Tests}

The tissue-culture techniques used will not detect parainfluenza or respiratory syncytial virus but will detect enteroviruses and adenoviruses in addition to rhinoviruses. Altogether 18 viruses were isolated from 59 patients $(30 \%)$. Three viruses were pathogenic for monkey-kidney cells-B632 and B633 belonging to the same serotype and one, B702, being identical with $\mathrm{JH}$ (E.C.H.O. 28). B632 and B633 were isolated in the period June 15 to July 25, 1961 (Table II) and the E.C.H.O. 28 viruses in the period September 25 to November 10, 1961. (Other viruses isolated in the latter period were H-type rhinoviruses.) Of nine tested so far none belong to the four serotypes already established for this group (Taylor-Robinson and Tyrrell, 1962).

In order to estimate the immune status of the population (so far as possible) and to look for evidence of infection in boys who had not been studied by virus isolation, we titrated sera collected from 21 boys in May, 1960 , and in May, 1961 - that is, before and after the period during which the viruses used in these tests had been isolated. It was found that of 21 sera collected in May, 1960, eight contained significant antibody $(K=0.2$ or greater-see Bynoe et al., 1961) against B632 and that there was a rise in titre in one of these and also in two of the 13 pairs of sera which showed titres of less than 0.2 in the first specimen. Five of 19 sera had antibody against E.C.H.O. 28 virus but there were no rises in antibody. Together with the virus isolations the results suggest that these viruses spread poorly in the community. When antibody to either virus was present, but not in rising titre, its level was practically unchanged, suggesting that naturally acquired antibody drops slowly, if at all, over the period of one year.

\section{Inocu'ation of Volunteers}

The results of inoculating adult volunteers with certain viruses are shown in Table IV. It seems that the

TABLE IV.-Inoculation of Washings to Volunteers

\begin{tabular}{|c|c|c|c|}
\hline Specimen & Date & $\begin{array}{c}\text { Type of Virus } \\
\text { Grown in Tissue } \\
\text { Culture }\end{array}$ & $\begin{array}{c}\text { No. of } \\
\text { Volunteers } \\
\text { Developing Colds }\end{array}$ \\
\hline $\begin{array}{l}\text { B632 } \\
\text { B702 }\end{array}$ & $\begin{array}{l}21 / 6 / 60 \\
29 / 9 / 61\end{array}$ & $\begin{array}{l}\text { M strain } \\
\text { E.C.H.O. } 28\end{array}$ & $\begin{array}{l}4 / 11^{*} \\
9 / 20\end{array}$ \\
\hline $\begin{array}{l}\text { B631 } \\
\text { B713 } \\
\text { B765 } \\
\text { B816 }\end{array}$ & $\begin{array}{l}20: 6 / 60 \\
14 / 10: 60 \\
101260 \\
24: 261\end{array}$ & $\begin{array}{l}\mathrm{H} \text { strain } \\
\mathrm{H} \text {,", } \\
\mathrm{H} \text { (grew badly) }\end{array}$ & $\begin{array}{l}0 / 5 \\
2 / 7 \\
2 / 8 \\
5 / 7\end{array}$ \\
\hline $\begin{array}{l}\text { B806 } \\
\text { B811 } \\
\text { B814 } \\
\text { B829 }\end{array}$ & $\begin{array}{l}4: 2 \\
13: 61 \\
13 / 2 \\
17 / 2 \\
22 / 3 \\
22\end{array}$ & $\begin{array}{l}\text { None } \\
,, \\
,,\end{array}$ & $\begin{array}{l}0 / 6 \\
2 / 6 \\
3 / 7 \\
0 / 6\end{array}$ \\
\hline
\end{tabular}

* Numerator $=$ number developing colds. Denominator $=$ numbe inoculated.

E.C.H.O. 28 and B632 strains both caused colds. Laboratory studies were made on most of these volunteers and will be published elsewhere, but it can be stated here that in general the results are similar to those obtained in earlier experiments (Tyrrell and Bynoe, 1968 ; Bynoe et al., 1961). Three of the four $\mathbf{H}$ strains also produced colds in volunteers and the fourth was inadequately tested. Furthermore, it can be seen that agents which could cause typical colds in volunteers were present in the washings collected in the spring term, although no viruses were detected in tissue cultures. Eaton's agent was circulating in the school at that time, but it has not been possible to isolate this agent from the specimens which were active in 
volunteers (Marmion, personal communication). Tests for respiratory syncytial and para-influenza virus were negative, and this and the fact that the specimens were active after repeated freezing and thawing make it unlikely that the agent was either respiratory syncytial or para-influenza virus.

The clinical features of the original mild colds, from which washings were taken and subsequently administered to volunteers, were compared with those developing in the latter. On the whole the symptoms were similar, but there was no correlation between the exact type of illness affecting the boy and that shown by the volunteer who received his virus. For example, although gastro-intestinal symptoms were prominent in certain cases none of the volunteers given these viruses had any gastro-intestinal symptoms. Also a boy might have scanty nasal secretion while the volunteer receiving his washing might have profuse nasal secretion; similarly, fever in the original colds was not correlated with fever in the volunteers. We conclude, therefore, that some other infectious agent was causing the gastrointestinal symptoms and that the clinical picture in each case was determined more by host factors than by the pathogenicity of the infecting virus.

\section{Discussion}

In this investigation we wished first of all to see if we could recover cultivable viruses from colds occurring in a defined population throughout the year. We found that we could isolate a virus from $30 \%$ of the cases that we tested, although we did not use methods that would detect para-influenza or respiratory syncytial viruses. All the viruses isolated behaved culturally like rhinoviruses and there was one isolation of E.C.H.O. 28, a virus which has characteristics like those of a rhinovirus.

The rate of isolation is similar to that which we achieved from stored nasal washings (Tyrrell and Bynoe, 1961). Other workers have also recovered viruses from a comparable proportion of specimens from common colds, both in this country (Hobson and Schild, 1960) and in the United States (Hamre and Procknow, 1961). The latter workers also isolated para-influenza and respiratory syncytial viruses among their total. In volunteer experiments (Tyrrell and Bynoe, 1961) virus was recovered from only two out of three cases of colds induced with cultivable viruses so that it seems likely that rhinoviruses were associated with a considerable proportion of the natural colds we studied.

As we had no specimens from boys without colds there was no epidemiological evidence that the viruses isolated were actually causing the illnesses observed, but such evidence has been obtained by others. Firstly, Hobson and Schild (1960) were able to isolate virus only during the acute stage of the illness; washings taken from colds 10 to 15 days after onset and from subjects without colds were always negative. In addition, Hamre and Procknow (1961) found a significant association between virus isolation and illness by comparing the isolation rates from acute and convalescent-stage specimens and those taken from asymptomatic persons. Extensive studies on volunteers inoculated with H.G.P. (Bynoe et al., 1961) and more limited work with other strains (Tyrrell and Bynoe, 1961) have shown that infection with these agents is associated with illness. We think, therefore, that rhino- viruses in general cause colds and that the viruses that we isolated probably caused the colds we saw.

In addition we have found in this study, as in earlier work, that the viruses isolated caused colds when administered to volunteers. We had clear evidence that the E.C.H.O. 28 virus produced typical colds in volunteers whereas earlier studies with virus grown in tissue culture had been inconclusive (Tyrrell and Bynoe, 1958). It is interesting that this virus was isolated by Hamre and Procknow in Chicago at about the same time in the early autumn that we made our single isolation. Their experience was also very similar to ours in other ways; they recovered few viruses in human embryo kidney from January to March, and isolated many H-type viruses in April and May.

In our earlier studies viruses were isolated from specimens collected far apart in space and time, and we found antigenic and biological differences among the strains isolated. In the present study we observed a similar variety of viruses following each other through a circumscribed community within the period of one year. We suspect that the occurrence of certain viruses may have been correlated with the fluctuations in the general pattern of illness in the group. On the other hand, we were unable to find correspondence between the clinical features of naturally occurring colds and illnesses produced in volunteers by instillation of the same viruses. This may have been due to age differences, to a variety of clinical effects being produced by a given virus, or to the artificial method of infecting volunteers. Further studies are required to resolve these uncertainties. Virus isolation should be attempted on a large number of cases and all the viruses isolated should be identified serologically. Then many cases due to a single type could be studied and the clinical manifestations of infection with each agent could be defined. This, together with a full serological study of the populations under observation, would probably go some way in explaining the epidemiological features of the common cold. However, it is also necessary to find techniques for growing the, so far, uncultivable agents.

\section{Summary}

Colds in boys aged 12-17 living in a boarding-school have been studied by clinical and laboratory methods.

The pattern and incidence of respiratory diseases fluctuated through the year, but in each term viruses were isolated in human-embryo-kidney cell cultures from nasal secretions from cases of colds. The overall rate was $30 \%$ from 59 cases. Two of four washings which did not yield viruses produced colds in volunteers.

The symptoms in the boys from whom viruses were recovered varied somewhat but could not be closely correlated with those found in the volunteers who received virus and also developed colds.

Serological findings showed that about two-thirds of the boys had no antibodies against two of the viruses present in the school (E.C.H.O. 28 and B632) and yet no epidemic developed, sugesting that these viruses spread poorly in the community.

We acknowledge with thanks the help given to us during this study by Dr. D. Stone and Dr. D. R. Gamble, successive Directors of the Public Health Laboratory, Epsom, who carried out the bacteriological tests; Dr. G. Cook, Director of the Public Health Laboratory, Guildford, who carried out the routine serological tests; Dr. T. S. L. Beswick, of 
the Biological Standards Laboratory, Hampstead, who sent us serum specimens; and the Distillers Company Ltd., Great Burgh, Epsom, who generously gave one of us (E. J. C. K.) supplies of " cardice."

\section{REFERENCES}

Andrewes, C. H., Burnet, F. M., Enders, J. F., Gard, S., Hirst, C. K., Kaplan, M. M., and Zhdanov, V. M. (1961). Virology, 15, 52.
Bynoe, M. L., Hobson, D., Horner, J., Kipps, A., Schild, G. C., and Tyrrell, D. A. J.'(1961). Lancet, 1, 1194.

Hamre, D., and Procknow, J. J. (1961). Brit. med. J., 2, 1382. Hobson, D., and Schild, G. C. (1960). Ibid., 2, 1414.

Taylor-Robinson, D., and Tyrrell, D. A. J. (1962). Lancet, 1 , 452.

Tyrrell, D. A. J., and Bynoe, M. L. (1958). Lancet, 2, 931.

— - (1961). Brit. med. J., 1, 393.

— and Parsons, R. (1960). Lancet, 1, 239.

\title{
HUMAN INFLUENZA VIRUSES IN DOMESTICATED ANIMALS
}

\author{
BY \\ P. N. MEENAN, M.D., D.C.P. \\ M. R. BOYD, B.A. \\ AND \\ ROISIN MULLANEY; M.R.C.V.S. \\ Department of Medical Microbiology, University College, Dublin
}

During the 1957 pandemic of Asian influenza W.H.O. initiated a study into the possible role of animals in the epidemiology of influenza (Kaplan and Payne, 1959). More than 20 countries participated, and the findings suggested that $\mathrm{A} 2$ viruses can cause inapparent infection in horses and swine, which were the only animals tested. In addition, serological evidence of A/equi influenza virus was discovered in countries which had not previously been aware of its presence. The results from the material tested in Ireland at that time were equivocal and no conclusions could properly be drawn from them.

The present study was undertaken in an attempt to elucidate the Irish findings and to attempt to enlarge or confirm those from other countries. Sera were collected at intervals from a variety of animals in Ireland from the early months of 1960 until the summer of 1961. During this time a major influenza epidemic occurred in January, 1961 (Meenan and Boyd, 1962).

\section{Materials and Methods}

Antigens.-The following strains of influenza virus were used: PR8 ; FM-1; A2/Asia/57; A2/Eire/8/61, isolated in Dublin during the 1961 epidemic ; A2/Asia/ 57(Ashton) and A2/Singapore/W/1/57, inhibitor insensitive strains forwarded to us by Professor Belyavin; A/equi/Praha/56 and A/swine/Shope/15/33, both forwarded by Sir Christopher Andrewes.

Sera.-Horse sera were obtained from two abattoirs in and near Dublin: a few were received from animals showing signs of respiratory infection. Swine sera were obtained from a Dublin meat-processing plant. Cattle sera were obtained from a Dublin abattoir. Poultry (hen) sera were obtained from a Dublin chickenprocessing factory. Cat and dog sera were obtained from veterinary dispensaries, and were from animals which were being destroyed. All sera were stored at $-20^{\circ} \mathrm{C}$. before use.

Complement-fixation (C.F.) Tests.-The method used was that of the W.H.O. (1953) Expert Committee on Respiratory Virus Diseases. PR8 virus was used for the preparation of soluble antigen.

Haemagglutination Inhibition (H.I.) Tests. - The method used was that of the W.H.O. (1953) Expert Committee on Respiratory Virus Diseases, except that the serum-virus mixtures were allowed to stand at room temperature for 30 minutes before the addition of red cells. Fowl red cells were used with W.H.O. pattern plastic plates.

The sera were treated as follows: $0.1 \mathrm{ml}$. of serum was heated for 30 minutes at $56^{\circ} \mathrm{C}$., after which $0.3 \mathrm{ml}$. of $M / 90$ potassium periodate was added and the mixture allowed to stand at room temperature for 30 minutes. Then $0.3 \mathrm{ml}$. of $1 \%$ glycerol-saline was added. A proportion of the horse sera was tested after similar treatment but without pre-heating. The results of the test were read by the pattern method after standing for one hour at room temperature.

Serum controls were included in each test, and sera showing direct agglutination of fowl red cells were omitted from the results.

Virus Isolation.-Throat and nasal swabs from animals with respiratory diseases were stored at $-20^{\circ} \mathrm{C}$. in $3 \mathrm{ml}$. of Hanks's lactalbumin containing $10 \%$ calf serum with added penicillin and streptomycin. Lung tissues from suspicious fatal cases were frozen and thawed quickly three times, centrifuged at 3,000 r.p.m. for 15 minutes, and, if necessary, stored at $-20^{\circ}$ C. before inoculation. All specimens were inoculated amniotically into $13-$ or 14-day chick embryos, and also into monkey-kidney and HeLa cell tissue cultures. The eggs were examined for evidence of growth of haemagglutinating viruses ; HeLa cells for cytopathogenic effect ; and the monkey-kidney cultures for cytopathogenicity, haemadsorption, and haemagglutination. All specimens were given a further blind passage.

\section{Results of Virus Isolation}

The results are shown in Table I. No viruses were recovered from any of the material examined.

\begin{tabular}{|c|c|c|c|c|c|}
\hline \multicolumn{3}{|c|}{ Animal } & 1960 & 1961 & Viruses Isolated \\
\hline $\begin{array}{l}\text { Cattle } \\
\text { Sheep } \\
\text { Poultry } \\
\text { Horse } \\
\text { Dog } \\
\text { Swine }\end{array}$ & $\begin{array}{l}\cdots \\
\therefore \\
\cdots \\
\therefore \\
\cdots\end{array}$ & $\begin{array}{l}\ldots \\
\cdots \\
\cdots \\
\ldots \\
\ldots\end{array}$ & $\begin{array}{r}10 \\
6 \\
9 \\
40 \\
15 \\
29\end{array}$ & $\begin{array}{r}0 \\
0 \\
0 \\
14 \\
1 \\
0\end{array}$ & $\begin{array}{l}0 \\
0 \\
0 \\
0 \\
0 \\
0\end{array}$ \\
\hline
\end{tabular}

\section{Serological Results}

$$
\text { C.F. Tests }
$$

Of the 2,157 sera examined, 369 were collected after the January, 1961, epidemic. The results are shown in Table II. It will be seen that with the exception of two 